\title{
NIEWINNA OFIARA? KSZTAŁTOWANIE SIĘ LEGENDY LADY JANE GREY W ŚWIETLE DZIEWIECTNASTOWIECZNEJ HISTORIOGRAFII I LITERATURY
}

Streszczenie. Celem niniejszego artykułu jest analiza legendy Jane Grey, która zaczęła się kształtować niedługo po jej egzekucji, która miała miejsce w 1554 r. W kolejnych stuleciach wizerunek „dziewięciodniowej królowej” w pracach historiograficznych i literackich zmieniał się w zależności od sytuacji politycznej w kraju. Nie bez znaczenia były również przekonania religijne autorów poszczególnych prac, gdyż katolicy i protestanci zupełnie inaczej opisywali wydarzenia, które miały miejsce w Anglii po śmierci Edwarda VI. Jane Grey jako wnuczka Marii Tudor, najmłodszej siostry Henryka VIII należała do elity arystokratycznej szesnastowiecznej Anglii. Należy także zaznaczyć, iż została ona uwzględniona w kolejnych aktach o sukcesji wydawanych przez monarchę, chociaż po bezdzietnej śmierci Edwarda to kolejno jego siostry i ich potomstwo, a dopiero później matka Jane i ona sama mogłyby liczyć na angielską koronę. Jednak będąc na łożu śmierci Edward VI zdecydował o zmianie prawa sukcesyjnego i mianowaniu swojej młodej kuzynki następczynią tronu. Decyzja ta sprowadziła Anglię na skraj wojny domowej i doprowadzała do tragicznej śmierci Jane Grey, i w konsekwencji do powstania jej legendy jako niewinnej protestanckiej męczennicy i ofiary katolickiej królowej Marii.

W artykule została dokonana analiza kronik, prac historiograficznych oraz dzieł literackich opisujących życie Jane Grey i wydarzenia z lat 1553-1554. Na podstawie porównania prac, które powstały w XIX w. z szesnastowiecznymi źródłami została ukazana legenda lady Jane Grey oraz zmiany jakim ona ulegała.

Słowa kluczowe: Anglia, XIX wiek, Jane Grey, John Dudley, Maria I, dynastia Tudorów, mit, legenda, historiografia, kroniki, angielska literatura, protestantyzm, katolicyzm. 
L

ady Jane Grey, znana przede wszystkim z przydomkiem „dziewięciodniowa królowa”, jest jedną z zapomnianych przedstawicielek dynastii Tudorów. Należy podkreślić, iż historia jej życia ciągle pozostaje w cieniu działalności jej sławnych kuzynek: Marii i Elżbiety. Zapewne jest to spowodowane bardzo wczesną śmiercią Jane oraz niezbyt dużym zasobem źródeł związanych z jej osobą. Należy również podkreślić, iż okres od śmierci Henryka VIII w 1547 r. do objęcia władzy przez jego najstarszą córkę w 1553 r., nie jest aż tak popularny, jak wcześniejsze i późniejsze rządy władców z dynastii Tudorów. Panowanie Jane Grey było tylko bardzo krótkim epizodem między śmiercią Edwarda VI, a objęciem tronu przez Marię I, dlatego też jej osoba jest często pomijana, bądź tylko wspominana przy opisywaniu wydarzeń w szesnastowiecznej Anglii. Ważną kwestią poruszaną przy omawianiu wydarzeń po śmierci Edwarda VI w lipcu 1553 r., jest kwestia zaliczenia Jane Grey w poczet angielskich władców. Należy wspomnieć, iż nigdy nie została ona koronowana na królową. Wątpliwości budzą również okoliczności, w jakich została mianowana następczynią tronu. My Device for the Succesion, w którym Edward VI zdecydował o zmianie sukcesji, nie zostało zatwierdzone przez parlament, tylko przez niechętnych tej decyzji lordów. Należy zaznaczyć, iż w pracach historiografów z XVIII czy XIX w. doskonale widać niespójność dotyczącą tytułowania Jane królową. Dylemat ten trwa do dziś. Z jednej strony Jane Grey uznawana jest za królową i jej życiorys umieszczany jest w pracach poświęconych kobietom na tronie. Jednak, oprócz Erica Ivesa, który uznał, że decyzja Edwarda o zmianie sukcesji była w pełni prawomocna i w lipcu 1553 r., to Maria była uzurpatorką ${ }^{1}$, żaden z pozostałych biografów Jane nie zdecydował się na tak jednoznaczne określenie.

Ważnym momentem w kształtowaniu się legendy Jane Grey i jej współczesnego wizerunku nie tylko w historiografii, ale także w kulturze powszechnej był wiek XIX. W tym okresie w literaturze i sztuce rozwinął się nurt romantyzmu, którego twórcy byli zafascynowani losami tragicznie zmarłych postaci. Jakkolwiek zainteresowanie życiem Anny Boleyn i Marii Stuart w tej epoce, w porównaniu do poprzednich, znacznie wzrosło, to w przypadku Jane można zaobserwować odwrotną tendencją. Na przełomie XVII i XVIII w. powstało znacznie więcej utworów literackich poświęconych jej tragicznemu życiu. Jednak zarówno w historiografii, jak i w malarstwie można odnotować wzmożone zainteresowanie losami Jane, a w przypadku malarstwa zwłaszcza ostatnimi chwilami przed jej egzekucją.

Należy zaznaczyć, iż XIX w. przyniósł duży rozwój historiografii, głównie dzięki działalności Leopolda von Ranke i zapoczątkowaniu przez niego

\footnotetext{
${ }^{1}$ E. Ives, Lady Jane Grey: a Tudor Mystery, Londyn 2009, s. 2.
} 
badania przeszłości poprzez krytyczną analizę źródeł i próbę ich bezstronnej analizy. Jest to widoczne również $w$ angielskiej historiografii poprzez wydawanie i opracowywanie wielu źródeł, które zostały wydane w dziewiętnastym stuleciu. Większość kronik czy dokumentów z panowania dynastii Tudorów została opublikowana w XIX w. i przyczyniła się do powstania licznych prac prezentujących życie poszczególnych monarchów oraz ich rodzin.

\section{Dziecko na tronie}

Osobą, która opisywała wydarzenia z przełomu końca panowania Edwarda VI i początku rządów Marii, a która miała nieco inną wizję znaczenia lady Jane Grey w spisku był John Lingrad (1771-1851), angielski historyk i katolicki duchowny. Należy wspomnieć, że jego rodzice również byli katolikami, gdyż odmówili przyjęcia wiary protestanckiej. Wychowywał się w Winchester, a studia ukończył w seminarium English College w Douai. Jego najsłynniejszym dziełem jest ośmiotomowa A History of England from the First Invasion by the Romans, której pierwsze wydanie ukazało się w latach 1819-1830². Praca ta doczekała się siedmiu wydań (do 1883 r.) i była najpopularniejszą dziewiętnastowieczną historią Anglii do czasu opublikowania w 1874 r. Short History of the English People autorstwa Richarda Greena ${ }^{3}$. Należy również zaznaczyć, że Lingard był pierwszym angielskim katolikiem w XIX w., który zdecydował się napisać pracę o dziejach Anglii. Krytycy najbardziej atakowali tomy dotyczące historii reformacji, oskarżając autora o bycie apologetą Kościoła Katolickiego. Jednak jak zaznacza John Vidmar, autor artykułu John Lingard's History of the English Reformation: History of Apologetics, Lingard popełniał w swojej pracy błędy, czasem nawet bardzo istotne, ale nie wynikały one z jego przekonań religijnych, tylko z braku dostępu do niektórych źródeł ${ }^{4}$.

W przeciwieństwie do historyków z XVII i XVIII w. ${ }^{5}$ Lingard wspomina o planach małżeństwa między Jane Grey i królem, których autorem był

2 P. Philips, Re-Evaluating John Lingard's History of England, https://www.cambridge.org/ core/journals/british-catholic-history/article/reevaluating-john-lingards-history-of-england/EEDC4F5496E6 984F A19F8D6F55A3BEBD (dostęp: 7.05.2019).

${ }^{3}$ P. Martyr, Fr John Lingard: Pioneer of Historical Research, http://www.churchinhistory. org/pages /leaflets/lingard.htm (dostęp: 7.05.2019).

${ }^{4}$ J. Vidmar, John Lingard's History of the English Reformation: History of Apologetics?, https://www.questia.com/library/journal/1P3-44502573/john-lingard-s-history-of-theenglish-reformation (dostęp: 7.05.2019).

${ }^{5}$ Zob.: A Complete History of England: with the Lives of all the Kings and Queens Thereof; From the Earliest Account of Time, to the Death of His Late Majesty King William III, vol. III, Londyn 1706; D. Hume, The History of England from the Invasion of Julius Caesar to the Revolution 
Thomas Seymour 6 . Była to pierwsza próba osadzenia na tronie wnuczki Marii Tudor, na której realizację liczyli jej rodzice. Jednak plan ten nigdy nie doszedł do skutku, ponieważ ówczesny Lord Protektor Edward Seymour ${ }^{7}$, myślał o małżeństwie monarchy z zagraniczną księżniczką, a nie jedną z poddanych. Natomiast ambicje polityczne młodszego z braci Seymourów przyniosły mu tragiczny koniec, który w 1554 r. spotkał także jego podopieczną.

W dalszej części autor dość szczegółowo opisuje plan sukcesji zawarty w testamencie Henryka VIII. Pod koniec wspomina jednak, że Dudley widząc pogarszający się stan zdrowia Edwarda, szepcze mu do ucha pomysły na zmianę woli jego ojca. Nową królową, zamiast Marii miałaby zostać Jane Grey, którą Northumberland uczynił swoją synową i której matkę przekonał, aby zrzekła się swych praw do korony na rzecz córki . Należy podkreślić, że najnowsze badania pokazują, że Frances Grey od początku była przeciwna planom uczynienia z córki samodzielnej władczyni, a także nie popierała przyłączenia się męża do rebelii Thomasa Wyatta9.

Autor przedstawia Northumberlanda jako bardzo gorliwego protestanta, który po śmierci Edwarda modli się, aby papiści nie wrócili do Anglii oraz

in 1688 in Six Volumes, vol. III, Nowy Jork 1983; R. Baker, A Chronicle of the Kings of England from the Time of Roman Government unto the Death of King James the First with the Continuation to the Year 1660 by E Phillips, Londyn 1733; T. Carte, A General History of England, vol. III, Londyn 1752.

6 Thomas Seymour, baron Sudeley (ok. 1508-1549), brat trzeciej żony Henryka VIII Jane i Lorda Protektora Edwarda Seymoura, księcia Somerset. W 1547 r. poślubił królową wdowę Katarzynę Parr. Po zawarciu związku małżeńskiego Seymour zamieszkał w posiadłości swej małżonki, gdzie przybywała także siostra króla Elżbieta. Relacja tych dwojga do tej pory pozostaje niejasna, jednak należy podkreślić, iż Sudeley zbyt zbliżył się do księżniczki, co przyczyniło się do wielu plotek. Seymour próbował również przeciągnąć na swoją stronę Edwarda VI i ograniczyć władzę swego starszego brata. Jego polityka zakończyła się fiaskiem. Został aresztowany i oskarżony o zdradę, a 20 marca 1549 ścięty. Zob.: G.W. Bernard, The Downfall of Sir Thomas Seymour, [w:] The Tudor Nobility, ed. by G.W. Bernard, Manchester 1992, s. 212-240.

${ }^{7}$ Edward Seymour, książę Somerset (ok. 1500-1552) był najstarszym bratem Jane Seymour, trzeciej żony Henryka VIII. W 1536 r. uzyskał tytuł wicehrabiego Beauchamp, rok później hrabiego Hertford, a w 1547 r. księcia Northumberland. Niedługo po śmierci Henryka VIII przyjął tytuł Lorda Protektora i Opiekuna Osoby Króla. Do jego upadku przyczyniały się: niechęć szlachty, nieudolna polityka zagraniczna, która doprowadziła do wypowiedzenia wojny przez Henryka II, bunty związane z polityka religijną, a także konflikt o władze z własnym bratem Thomasem Seymourem i jego egzekucja w 1549 r. E. Seymour został obalony przez Johna Dudleya w 1550 r. i ścięty 2 lata później za spiskowanie przeciwko niemu. Zob.: S. Bryson, Edward Seymour, Duke of Somerset, https://sarah-bryson.com/2018/10/20/edward-seymourduke-of-somerset/ (dostęp: 2.12.2018).

${ }^{8}$ J. Lingard, A History of England from the First Invasion by the Romans, vol. IV, Paris 1840, s. 286-287.

9 N. Tallis, Crown of Blood. The Deadly Inheritance of Lady Jane Grey, Londyn 2017, s. 242-247. 
aby ani Maria, ani Elżbieta nie rządziły krajem ${ }^{10}$. Wydaje się, że pragnienie Dudleya miało raczej charakter polityczny, a jego stosunek do wiary był dość ambiwalentny, o czym świadczy choćby zmiana wyznania tuż przed śmiercią. Natomiast wykluczenie Elżbiety na równi z Marią było tłumaczone tym, że obydwie zostały uznane przez Henryka VIII za bękarty, co według Northumberlanda powinno automatycznie pozbawić je praw do tronu.

Lingard w interesujący sposób przedstawia czytelnikowi osobę Jane Grey. Twierdzi on bowiem, że była ona uzależniona od nauki i studiowania starych pism oraz najlepiej czuła się z dala od zainteresowania otaczających ją ludzi. Zapewne miało to tłumaczyć jej brak zrozumienia sytuacji panującej na dworze oraz nieznajomość planów teścia. Autor przedstawia ją również jako bardzo emocjonalną dziewczynę, która, kiedy dowiedziała się o planach Northumbelrnada zemdlała, a po ocknięciu się stwierdziła, że nie nadaje się na królową, ale jeśli rzeczywiście korona jej się należy, to Bóg będzie po jej stronie $^{11}$. Można zauważyć, iż autor częściowo odnosi się do przekazu Polliniego, gdy wspomina, że Jane straciła przytomność, jednak od siebie dodaje komentarz o oddaniu losu w ręce Boga.

Należy również zaznaczyć, że Lingard uważa, iż wszystkie relacje o tym, że Jane odmówiła korony, zostały stworzone przez historyków, aby ubarwić opowieść o niej, jednak zapominają, że miała ona wtedy tylko szesnaście lat ${ }^{12}$. Moim zdaniem Jane mogła odmówić przyjęcia korony, gdyż uważała, że jej się ona nie należy. Swój sprzeciw wobec planów teścia wyraziła jasno w liście do Marii oraz w trakcie przemówienia na szafocie. Myślę, że nie należy jej postrzegać tylko jako młodej dziewczyny, która nic nie wiedziała o życiu i nie miała własnego zdania, ponieważ jej sprzeciw wobec małżeństwa czy koronacji Guildforda na króla Anglii świadczą, o tym, że miała silny charakter, którego odzwierciedlenie delikatnie widać w relacjach szesnastowiecznych kronikarzy, ambasadorów i jej nauczycieli.

Kolejną kwestią poruszoną przez Linagarda są okoliczności przejęcia władzy przez Marię i likwidacja krótkiego panowania jej młodszej krewnej. Później autor wspomina o tym, że cesarscy ambasadorowie chcieli szybkiego sądu i egzekucji Jane, jako uzurpatorki zagrażającej pozycji Marii. Jednak królowa odmówiła, gdyż w jej oczach dziewczyna była tylko marionetką w rękach Northumberlanda. Lingard wspomina także, że małżeństwo Jane nie było ważne, ponieważ zanim poślubiła Guildforda Dudleya była obiecana Edwardowi Seymourowi, synowi zmarłego Lorda Protektora ${ }^{13}$. Według Marii

\footnotetext{
${ }^{10}$ J. Lingard, dz. cyt., s. 297.

11 Tamże, s. 297.

12 Tamże, s. 298.

${ }^{13}$ Zob.: N. Tallis, dz. cyt., s. 132-134.
} 
świadczyło to, że jej kuzynka została zmuszona zarówno do ślubu, jak i do przyjęcia korony przez podstępnego i ambitnego księcia Northumberland. Należy zaznaczyć, że brak jest źródeł świadczących o takich argumentach Marii dotyczących przyszłości jej krewnej.

Następnie autor opisuje egzekucję Jane i Guildforda, które były następstwem buntu przeciwko władzy Marii. Lingard stwierdza, że Jane jako osoba pochodząca z królewskiej rodziny została stracona wewnątrz Tower, w przeciwieństwie do wcześniejszych autorów nie wiąże tego z obawami o reakcję ludności na śmierć młodej i niewinnej osoby. Należy wspomnieć, że pisze on o obecności Feckenhama podczas ostatnich chwil Jane, jednak pomija milczeniem próbę nawrócenia podjętą przez duchownego. Być może przemilczenie tego wydarzenia wiązało się z wyznaniem autora oraz niechęcią do ukazania porażki katolicyzmu. Należy jednak podkreślić, iż mimo swoich poglądów religijnych Lingard uznał, że młody wiek Jane przemawiał za tym, by ją oszczędzić, potencjalne ryzyko związane z ponownym podniesieniem jej praw do tronu można było zażegnać w inny sposób ${ }^{14}$. Niestety nie podaje jaki. Opinia ta jest zgodna z obrazem Jane kreowanym przez autora. Dla niego była ona tylko młodą i bezwolną, zapatrzoną w książki dziewczyną, dlatego też nie uznawał jej za zbyt wielkie zagrożenie dla rządów Marii.

\section{Bohaterka licznych biografii}

W XIX w. wieku powstały liczne biografie prezentujące życie Jane, jej sióstr oraz teścia ${ }^{15}$. Ich autorzy starali się zaprezentować dość bezstronny opis wydarzeń z lat 1536 - 1554, jednak nie zawsze odnosili zmierzony skutek, zwłaszcza przy prezentowaniu motywów postępowania Johna Dudleya, księcia Northumberland ${ }^{16}$. Jednym z autorów, który poświecił swą pracę

\footnotetext{
14 J. Lingard, dz. cyt., s. 330-331.

15 R. Davey, The Sisters of Lady Jane Grey and their Wicked Grandfather, Londyn 1911; N.H. Nicolas, The Literary Remains of Lady Jane Grey with a Memoir of her Life, Londyn 1825.

${ }^{16}$ John Dudley, książę Northumberland (ok. 1502-1553) w latach 1537-1547 pełnił funkcję Lorda Admirała, w 1547 r. został mianowany hrabią Warwick, a w 1551 r. księciem Northumberland. W latach 1549-1553 stał na czele Rady Regencyjnej. Wraz ze swoją żoną Jane Guildford miał 13 dzieci. Najmłodszy z jego synów Guildford Dudley został mężem Lady Jane Grey, którą w 1553 r. po śmierci Edwarda VI chciał uczynić królową Anglii. Jednym z jego potomków był także Robert Dudley, faworyt Elżbiety I. Po dojściu do władzy przez Marię Tudor John Dudley został osądzony i ścięty 22 lipca 1553 r. Niedługo przed egzekucją powrócił do wiary katolickiej, być może licząc na łaskę ze strony królowej. Zob.: J. Dudley, Vicount of Lisle, Earl of Warwick, Duke of Northumberland (c. 1502-1553), http://www.luminarium.org/encyclopedia/northumberland.htm (dostęp: 2.12.2018); B.L. Beer, The Myth of the Wicked Duke and the Historical John Dudley, "Albion: a Quarterly Journal Concerned with British Studies" 1979 , t. 11, nr 1, s. 1-14.
} 
opisaniu życia Jane był William Godwin (1756-1836), autor wydanej w $1824 \mathrm{r}$. książki Life of Lady Jane Grey and of Lord Guildford Dudley, Her Husband.

We wstępie autor zaznacza, iż jest to praca dla młodzieży pragnącej zapoznać się z wydarzeniami z 1553 r. i ze wzorem godnym do naśladowania, jakim była Jane Grey ${ }^{17}$. Praca ta składa się z sześciu rozdziałów opisujących życie Jane od jej narodzin i edukacji, aż do jej śmierci. Należy zaznaczyć, iż autor zawarł w biografii listy Jane do siostry i ojca oraz jej debatę z Feckenhamem. Godwin podaje również jej rok urodzenia jako $1537^{18}$, nie wiadomo jednak, skąd czerpał tę informację, gdyż w żadnym współczesnym Jane źródle nie jest odnotowana data jej narodzin. W dalszej części podkreśla jej wykształcenie, znajomość języków oraz edukację w towarzystwie Elżbiety i Edwarda. Zgodnie z duchem epoki, autor przybiera moralizatorski ton i twierdzi, że Jane oprócz nauki celowała również w innych zajęciach odpowiednich dla jej płci, jak chociażby szycie czy gra na instrumentach ${ }^{19}$. Należy podkreślić, iż Godwin jest również zaznajomiony z twórczością R. Aschama i cytuje jego relację dotyczącą spotkania z Jane. Dydaktyczne założenia Achama były bardzo popularne w wiktoriańskiej Anglii, dlatego też wielu twórców piszących o Jane odwoływała się do jego dzieła The Schoolmaster. Interesujące jest, że Godwin nie zwraca uwagi na fragmenty dotyczące fizycznego znęcania się, jakiego doświadczyła dziewczyna, natomiast podkreśla on znaczenie odpowiedniego systemu edukacji dla prawidłowego rozwoju ${ }^{20}$. Jest to zapewne związane z innym postrzeganiem bicia dzieci niż współcześnie i to, co może szokować nas, niekoniecznie było czymś niezwykłym dla ludzi żyjących w XIX w.

Na kolejnych stronach Godwin dużo miejsca poświęca niechęci Jane względem przyjęcia korony, która jej się nie należy oraz jej zgodę spowodowaną przedstawieniem jej przez teścia tragicznego losu, jaki może spotkać jej rodzinę, jeśli nie wyrazi na to zgody ${ }^{21}$. Później opisuje przejęcie władzy przez Marię oraz pełną spokoju i godności postawę Jane wobec utraty korony, co jest zapewne zaczerpnięte z kroniki Bakera bądź z jednej następujących po niej prac dotyczących historii Anglii.

W dalszej części autor wspomina o procesie Jane oraz o rebelii Wyatta, która przyczyniła się do decyzji o wykonaniu wyroku. Godwin podkreśla, że choć Maria zdecydowała się na egzekucję krewnej, to jednak dbała

17 W. Godwin, Life of Lady Jane Grey and of Lord Guildford Dudley, Her Husband, Londyn 1823, s. III-IV.

\footnotetext{
18 Tamże, s. 3.

19 Tamże, s. 8-9.

20 Tamże, s. 12-16.

21 Tamże, s. 44-45.
} 
o jej duszę i przysłała do niej swego kapelana Johna Feckenhama. Przy opisie ostatnich trzech dni przed egzekucją autor cytuje listy napisane przez Jane do krewnych ${ }^{22}$. Oprócz krytyki zachowania Feckenhama, który według Godwina nawet na szafocie chciał nawrócić Jane na katolicyzm ${ }^{23}$, przebieg przybycia skazanej na miejsce stracenia oraz jej śmierć są zgodne z szesnastowiecznymi przekazami.

Pozostałe biografie Jane Grey powstałe w XIX w. przedstawiają identyczny obraz charakteru „dziewięciodniowej królowej”, jej reakcji na objecie tronu oraz jego utratę, a także jej ostatnich chwil w Tower oraz egzekucji. Poszczególni autorzy zwracają uwagę na niepełne informacje dotyczące jej życia, które utrudniają jego opis ${ }^{24}$ lub po odkryciu nowych materiałów wytykają błędy poprzedników oraz krótko wspominają o literackich wcieleniach Jane Grey ${ }^{25}$. Jednak jej obraz jako świetnie wykształconej, niewinnej ofiary knowań Northumberlanda i jego zwolenników pozostaje niezmienny.

\section{„Słodkie jest nasze odejście z pełnego dumy świata”26}

W XIX w., jak i we wcześniejszych epokach również powstawały utwory literackie zainspirowane tragicznymi losami Jane Grey. Duży wpływ na utrzymujące się zainteresowanie życiem nieszczęsnej królowej miało pojawienie się w literaturze i sztuce idei romantyzmu. Nie tylko Jane Grey, ale również Anna Boleyn czy Maria Stuart stały się bohaterkami kolejnych oper, wierszy, obrazów czy powieści, które miały przybliżyć ludziom ich tragiczne życie.

Należy również wspomnieć, iż pozycja Jane w dziewiętnastowiecznych utworach ulega zmianie. Jest to głównie związane ze zmianą postrzegania roli kobiety w społeczeństwie. W Anglii oraz innych państwach zaczęła się rozwijać ideologia „oddzielnych sfer”. Do kobiet należała sfera domowa, a do mężczyzn cały pozostały świat ${ }^{27}$. Jest to widoczne w kreowaniu postaci Jane, gdyż mimo że jest ona wykształcona, to głównie marzy o spokojnym życiu na wsi w otoczeniu rodziny. Jest to już widoczne w utworach z końca XVIII w., jednak autorzy epoki romantyzmu zdecydowanie bardziej podkreślają uczu-

22 Tamże, s. 90-95.

23 Tamże, s. 101.

24 G. Howard, Lady Jane Grey and Her Times, Londyn 1822, s. 9.

25 N.H. Nicolas, Memoirs and Remains of Lady Jane Grey, Londyn 1831, s. I-VI; P. Sidney, Jane the Quene. Being Some Account of the Life and Literary Remains of Lady Jane Dudley Commonly Called Lady Jane Grey, Londyn 1900, s. 107-120.

${ }^{26}$ F. Hodgson, Lady Jane Grey a Tale in Two Books; with Miscellaneous Poems in English and Latin, Londyn 1809, s. 40.

${ }^{27}$ K. Hughes, Gender Roles in the $19^{\text {th }}$ Century, https://www.bl.uk/romantics-and-victorians/articles/ gender-roles-in-the-19th-century (dostęp: 2.06.2019). 
ciowość Jane, która miała wpływ na jej osąd oraz podejmowane przez nią decyzje. $W$ ich twórczości można również dostrzec wzmocnienie pozycji Guildforda. To on jest osobą decyzyjną i ma największy wpływ na Jane.

Francis Hodgson, poeta i tłumacz był jednym z autorów, który stworzył dzieło zainspirowane życiem Jane Grey. Poemat Lady Jane Grey a Tale in Two Books został po raz pierwszy wydany w 1809 r. i rozpoczyna się od spotkania głównej bohaterki z Rogerem Aschamem, kończy na jej egzekucji, a cała akcja rozgrywa się w trakcie ostatnie roku panowania Edwarda VI. We wstępie autor przedstawia osoby występujące w utworze, równocześnie podkreślając, iż przekłamania oryginalnej historii występujące w poemacie nie są ani duże, ani znaczące i ma nadzieję, że nikt nie będzie mu ich wypominał ${ }^{28}$.

Można zauważyć, iż autor jest dobrze zaznajomiony z pracą Rogera Aschama The Schoolmaster, ponieważ utwór rozpoczyna od przedstawienia Jane czytającej Platona, podczas gdy pozostali członkowie jej rodziny udali się na polowanie. Zaczytaną dziewczynę podziwia Ascham, który ze zdziwieniem wyraża się o swej byłej uczennicy: „Jak może tak młoda, beztroska, piękna panna uciekać od jowialnej zabawy i miłości”29. W dalszej części podmiot liryczny wychwala wykształcenie Jane oraz jej zamiłowanie do nauki, a także podkreśla, iż jest ona jedyną osobą z rodziny królewskiej, która jest pełna cnót ${ }^{30}$.

Kolejną osobą pojawiającą się w utworze jest Guildforda Dudleya. Podmiot liryczny twierdzi, że chłopak był uwielbiany na dworze i nieustraszony $\mathrm{w}$ pojedynkach oraz jednocześnie szczery w uczuciach do Jane. Nazywa go również dziedzicem Warwicka ${ }^{31}$, nie jest to prawda, gdyż Guildford był dopiero czwartym synem Johna Dudleya i nie był postrzegany jako „dobra partia" dla członkini rodziny królewskiej.

Pierwsza część poematu kończy się nakłonieniem Suffolka przez Warwicka do poparcia kandydatury Jane jako następczyni tronu, gdyż „nasz król niedługo może nas opuścić i wróci do nas władza Rzymu; Elżbieta z winy matki nie może zostać królową, a Szkoci przywiodą nas pod francuskie ber$ł^{\prime \prime 32}$. Słowa te uwidaczniają obawy protestantów przed powrotem na tron katolickich władców. Można zauważyć, iż Hodgson lepiej niż jego poprzednicy przedstawia powód wykluczenia Elżbiety na równi z Marią. Niektórzy

${ }^{28}$ F. Hodgson, dz. cyt., s. VII.

29 Tamże, s. 4-7.

30 Tamże, s. 8.

31 Zamiast hrabia Warwick, powinien być użyty książę Northumberland, gdyż John Dudley, ojciec Guildforda od 1551 r. posiadał tytuł księcia, a akcja utworu rozgrywa się w 1553 r.; F. Hodgson, dz. cyt., s. VIII, 12-13.

${ }^{32}$ F. Hodgson, dz. cyt., s. 14. 
historycy, jak na przykład G. Burnett nie mogli pojąć, dlaczego młodsza córka Henryka VIII była wykluczona, skoro była protestantką ${ }^{33}$.

Druga część utworu rozpoczyna się od opisu posiadłości rodzinnej Suffolków Bradgate, która stała się miejscem, gdzie rozkwita miłość Jane i Guildforda. Ich spokój burzy informacja o śmierci Edwarda. W nocy w posiadłości następczyni Edwarda słyszy głos przewidujący rychłą śmierć jej i Guildforda $^{34}$. W dalszej części utworu teść ofiaruje Jane koronę, ta odmawia, gdyż uważa, że władza królewska jej się nie należy, jednak ostatecznie jest zmuszona ją przyjąć ${ }^{35}$. Pozostała część poematu poświęcona jest przejęciu władzy przez Marię. Podmiot liryczny przedstawia Jane jako bardzo religijną dziewczynę, która modli się za męża, mimo że cierpi z jego powodu, gdyż to on przekonał ją do zmiany decyzji dotyczącej korony ${ }^{36}$. Należy podkreślić, iż także Maria przedstawiona jest w bardzo negatywnym świetle. Zostaje ona nazwana „siostrą okrucieństwa”37, która w sekrecie każe przygotować szafot dla więźniów.

Ostatnią część utworu Hodgson poświęca próbie nawrócenia Jane na katolicyzm. Duchowny przysłany przez Marię ponosi jednak klęskę, gdyż skazana nie potrzebuje pocieszenia przed śmiercią, a zbliżający się koniec podsumowuje słowami: „słodkie jest nasze odejście z pełnego dumy świata” ${ }^{38}$. Podkreślony jest również jej negatywny stosunek do niespodziewanej konwersji teścia, którą nazywa "grzechem tchórza”39. Jane pozostaje wierna swej wierze i wydaje się, że nic już jej nie wzruszy przed śmiercią. Jednak, gdy obserwuje idącego na szafot Guildforda płacze i mdleje, gdyż nie może patrzeć na jego śmierć. Wkrótce udaje jej się opanować wzruszenie i obserwuje ostanie chwile męża. Jej ostatnie momenty przed egzekucją wypełnione są modlitwą, a jej ostatnie słowa skierowane są do kata, którego prosi, aby szybko wykonał wyrok ${ }^{40}$.

W utworze Hodgsona można zauważyć przede wszystkim duże odwołania do relacji R. Aschama. Poeta podkreśla zamiłowanie Jane do nauki oraz chwali jej charakter i wykształcenie. Znaczna część poematu poświęcona jest również miłości Jane do męża. Jest to wątek pojawiający się w literaturze już od końca XVI w., mimo że nie miał nic wspólnego z rzeczywistą relacją

${ }^{33}$ G. Burnet, The History of the Reformation of the Church of England, vol. II, Oxford 1816, s. 410 .

${ }^{34}$ F. Hodgson, dz. cyt., s. 22-23.

35 Tamże, s. 28-29.

${ }^{36}$ F. Hodgson, dz. cyt., s. 41.

37 Tamże, s. 39.

38 Tamże, s. 40.

39 Tamże, s. 41.

40 Tamże, s. 45-46. 
małżonków. Jane Grey przedstawiona jest także jako zagorzała protestantka, gotowa poświecić wszystko dla swej wiary, gdyż życie ziemskie nie jest warte tyle, co możliwość oglądania bożego oblicza.

\section{W cieniu Tower}

Gatunkiem literackim, który znacznie rozwinął się w XIX w. była powieść historyczna. Spisek z lipca 1553 r. dla pisarzy był fascynującym momentem z dziejów Anglii, w związku z tym powstały powieści, w których pojawia się Jane Grey. Należy podkreślić, iż nie jest ona tam główną bohaterką, a większość akcji toczy się z pominięciem jej osoby.

Jednym z autorów, który w swej powieści opisał losy Jane był William Harrison Ainsworth (1805-1882), angielski dziennikarz, pisarz i poeta. Jego najbardziej znanymi powieściami są Rookwood i The Lancashire Witches. Chociaż Ainsworth był częścią wczesno-wiktoriańskiej elity pisarskiej, jego zbyt sentymentalny styl był często krytykowany i wyśmiewany ${ }^{41}$. Powieść The Tower of London a Historical Romance została po raz pierwszy wydana w Londynie w 1840 r. Jej akcja toczy się między 10 lipca 1553 r. a 12 lutego 1554 r. i koncentruje się na krótkim panowaniu Jane, jej upadku i zwycięstwie Marii. Należy dodać, iż w książce tej znajduje się 40 rycin i 54 drzeworyty autorstwa George'a Cruikshanka, wybitnego karykaturzysty i ilustratora.

Powieść rozpoczyna się opisem przybycia Jane do Tower. Wokół twierdzy zebrał się wielki tłum, lecz panuje głucha cisza, gdyż nikt nie cieszy się z wyboru nowej królowej. Przed wejściem do zamku jedna z kobiet ostrzega Jane, aby tam nie wchodziła, bo czeka ją tylko tragiczny los. Powieść pełna jest takich symbolicznych wskazówek dotyczących losu nowej królowej. Podczas pierwszej nocy w Tower Jane ukazuje się topór, zwiastujący jej późniejszą egzekucję ${ }^{42}$.

Ważnym elementem powieści Ainswortha jest relacja Jane i jej męża. Autor wspomina, że Guildford był osobą, która miała największy wpływ na decyzję żony o przyjęciu pozycji królowej ${ }^{43}$. W dalszej części książki można dostrzec, że główna bohaterka jest bardzo zakochana w mężu i za wszelką cenę star się utrzymać go przy życiu oraz czyni wszystko, aby był on zawsze przy niej. Jedynym wyjątkiem jest próba uczynienia Guildforda królem przez Northumberlanda i pozostałych lordów. Jane opiera się, co doprowadza do kłótni z mężem i opuszczenia przez niego Tower. Zachowanie Guildforda

${ }^{41}$ About W.H. Ainsworth, https://ainsworthandfriends.wordpress.com/about-w-h-ainsworth/ (dostęp: 2.06.2019).

${ }^{42}$ W.H. Ainsworth, The Tower of London a Historical Romance, Londyn 1840, s. 3-4.

43 Tamże, s. 13, 32. 
doprowadza jego żonę do rozpaczy, zamyka się ona w komnacie i płacze ${ }^{44}$. Pokazuje to, iż z jednej strony Jane potrafiła podejmować samodzielne decyzje, z drugiej zaś była tylko emocjonalną dziewczyną, która w chwili załamania nerwowego nie była w stanie sprawować władzy.

Jane Grey w powieści Ainswortha jest całkowicie nieświadoma tego, co się wokół niej dziej, daje się łatwo nabrać na podstępne kłamstwa cesarskiego ambasadora Renarda, który spiskuje, aby przywrócić na tron Marię. Kiedy sytuacja staje się beznadziejna, wysłannik Karola $\mathrm{V}$ próbuje namówić królową, aby abdykowała i w ten sposób uratowała siebie i męża. Zaskakujące jest to, że Jane odmawia. We wszystkich wcześniejszych utworach była przedstawiana jako osoba chętnie rezygnująca z ciężaru, jaki na nią spadł. W tej powieści natomiast uparcie trwa przy swej racji i stanowczo twierdzi, iż to ona jest prawowitą królową Anglii ${ }^{45}$. Jej upór nie trwa jednak długo, gdyż wkrótce rada buntuje się przeciwko niej i ogłasza nową władczynią Marię, co równoznaczne jest z pozbawieniem tronu Jane oraz uwięzieniem jej i Guildforda.

Kolejnym ważnym wątkiem powieści jest próba zmuszenia młodych małżonków do konwersji na katolicyzm. Feckenham i Gardiner przedstawieni są jako podstępni duchowni, którzy szantażem próbują zmusić Jane do zmiany wyznania. Narzędziem, które ma im w tym pomóc, jest miłość Jane do męża. Feckenham twierdzi, iż powie Guildfordowi, że Jane go nie kocha, nazywa ją jego katem, gdyż przyczynia się do jego śmierci ${ }^{46}$. Żadne groźby nie są jednak w stanie złamać wiary „dziewięciodniowej królowej”, która ostatecznie stwierdza: „urodziłam się w protestanckiej wierze i jako protestantka umrę"47.

W przeciwieństwie do rzeczywistych wydarzeń Jane wraz z mężem zostaje uwolniona z Tower i może cieszyć się wolnością. Nie trwa to jednak długo, gdyż tak jak w powieści Lady Jane Grey an Historical Tale in Two Volumes Guildford przyłącza się do spisku przeciw Marii, co doprowadza do ich ponownego uwięzienia i egzekucji. Należy również zaznaczyć, iż w tej wersji wydarzeń Jane spotyka się z Marią i błaga ją o przebaczenie dla męża. W przeciwieństwie do innych utworów, które prezentują najstarszą córkę Henryka VIII jako żądną krwi fanatyczkę, Ainsworth ukazuje ją w dość neutralnym świetle. Na prośby kuzynki odpowiada: „dla Twojego dobra chciałabym go oszczędzić Jane, lecz nie mogę"48. Ostatecznie propo-

\footnotetext{
${ }^{44}$ Tamże, s. 37, 65-67.

45 W.H. Ainsworth, dz. cyt., s. 99.

${ }^{46}$ Tamże, s. 177.

47 Tamże, s. 181.

48 Tamże, s. 341-342.
} 
nuje zrozpaczonej dziewczynie zmianę wyznania albo śmierć. Jane wybiera śmierć. Przebieg wydarzeń z szafotu jest zgodny z szesnastowiecznymi kronikami ${ }^{49}$, co świadczy o tym, iż autor, chociaż częściowo zapoznał się ze źródłami historycznymi.

Jane Grey w powieści Ainswortha przedstawiona jest jako uparta, naiwna, bez pamięci zakochana w mężu i bardzo emocjonalna dziewczyna. Jedynym punktem jej życia, który jest odporny na perswazje otaczających ją ludzi, jest religia, której pozostaje wierna do końca, nawet jeśli konwersja na katolicyzm miałaby skutkować ocaleniem siebie i Guildforda.

Drugą powieścią z XIX w., w której pojawia się Jane jest Lady Jane Grey a Historical Romance autorstwa Thomasa Millera (1807-1874). Praca ta, jak i The Tower of London a Historical Romance również została wydana w Londynie w $1840 \mathrm{r}$. Jednak mimo tytułu świadczącego o znacznym udziale Jane w przebiegu akcji, powieść ta koncentruje się na wątku zemsty gorliwej katoliczki Duskeny, która straciła swoje dzieci w trakcie rządów Edwarda. W powieści tej również można odnaleźć wiele symbolicznych znaków świadczących o tragicznym losie, jaki czeka Jane. Duskena posiada dar przewidywania przyszłości i choć mówi Northumberlandowi, iż jego plan się powiedzie, to dodaje, że zdobyta korona „spłynie krwią"50. Autor podkreśla, że Jane nigdy nie chciała zostać królową, co najlepiej wyrażają słowa: „umrę za wiarę, lecz nigdy nie uzurpuję władzy królewskiej" ${ }^{1}$. Powieść kończy się opisem próby nawrócenia Jane przez Gardinera i Feckenhama oraz jej egzekucją, która wzbudza rozpacz Duskeny i przyczynia się do jej rezygnacji z zemsty na protestantach ${ }^{52}$.

\section{Polska perspektywa}

W 1830 r. Juliusz Słowacki napisał dramat Maria Stuart. Został on wystawiony dopiero w 1862 r. we Lwowie. Być może to przedstawienie zainspirowało Władysława Tarnowskiego (1836-1878), polskiego pianistę, kompozytora, poetę i dramaturga ${ }^{53}$ do stworzenia własnej sztuki przedstawiających tragiczne życie Jane Grey. Zaskakującym może być jednak wybór głównej bohaterki sztuki. Bez wątpienia bardziej popularną angielską

49 The Chronicle of Queen Jane and of Two Years of Queen Mary and Especially of the Rebellion of sir Thomas Wyat. Written by the Resident in the Tower of London, ed. J.G. Nichols, Londyn 1850 , s. 56-59.

50 T. Miller, Lady Jane Grey a Historical Romance, Londyn 1840, s. 27.

51 Tamże, s. 136.

52 Tamże, s. 200-201.

${ }^{53}$ Władysław Tarnowski, h. Leliwa, https://www.ipsb.nina.gov.pl/a/biografia/wladyslaw-tarnowski-h-leliwa (dostęp: 3.06.2019). 
królową, która również została ścięta była Anna Boleyn. Autor zdecydował się jednak zapoznać publiczność z życiem mniej znanej członkini angielskiej rodziny królewskiej.

Dramat Joanna Grey. Obraz tragiczny z XVI wieku został wydany po raz pierwszy we Lwowie w 1875 r. i składa się z pięciu odsłon. Utwór rozpoczyna się przedstawieniem Jane w otoczeniu artystów i naukowców, a kończy się jej egzekucją. Główna bohaterka dramatu przedstawiona jest jako kochająca naukę dziewczyna (w pierwszej scenie siedzi w otoczeniu książek, a na półce stoi popiersie Platona ${ }^{54}$ ). W dramacie Tarnowskiego można dostrzec dużą inspirację twórczością R. Aschama, a zwłaszcza jego pracą The Schoolmaster. Dramaturg przedstawia relacje Jane z rodziną właśnie na podstawie tej książki. Frances Grey ukazana jest jako znęcająca się nad córką, ordynarna kobieta, która myśli tylko o strojach i zabawie ${ }^{55}$.

Jane kreowana jest przez autora na ideał kobiety oraz królowej. Z jej ust pada między innymi stwierdzenie: „Ja — gdybym była królową, choć jestem protestantką, nie prześladowałabym katolików, nie paliłabym żydów ani anabaptystów - ludzie dobrej woli, byli by mi wszyscy pożądani" ${ }^{\prime \prime}$.

Taka postawa jest sprzeczna, choćby z listem, który napisała, będąc więźniem w Tower do byłego kapelana swego ojca, który zmienił wiarę na katolicyzm, co wywołało oburzenie i obelgi ze strony Jane ${ }^{57}$. Jej tolerancyjna postawa w dramacie łączy się przede wszystkim z toastem. jaki wznosi za zdrowie ludzi wykształconych:

za zdrowie Humanistów, a naprzód wolnomyślnégo króla Polski Zygmunta Augusta! którego wyrozumiałość przygarnia światłych a prześladowanych! Jeżeli jest szczypta sprawiedliwości na świecie, to kiedyś wolna Europa uczci ten naród, co nas broni od napaści Wschodu — a z Zachodu prześladowanych przygarnia gościnnie! Im ludzkość dłużna! niech żyją wieki! ${ }^{58}$

Cytat ten wyraża raczej poparcie autora dla niepodległościowych dążeń Polaków niż rzeczywiste uwielbienie Jane dla Polaków, o których pewnie nie wiedziała nic, bądź bardzo niewiele.

54 W. Tarnowski, Joanna Grey. Obraz tragiczny z XVI wieku, Lwów 1874, s. 9.

55 Tamże, s. 12, 28. Nie można jednak wysuwać, aż tak kategorycznych wniosków dotyczących Frances Grey i jej relacji z najstarszą córką, ponieważ istnieją przekazy z epoki świadczące o ich dobrych kontaktach. Zob.: N. Tallis, dz. cyt., s. 103-104.

56 W. Tarnowski, dz. cyt., s. 21.

57 The Acts and Monuments of John Foxe: a New and Complete Edition, vol. VI, ed. S.R. Cattley, Londyn 1838, s. 419. W liście tym Jane nazywa Thomasa Hardinga „zdeformowanym karłem szatana" oraz twierdzi, iż zalicza się on teraz do kręgu rzymskich antychrystów.

${ }^{58}$ W. Tarnowski, dz. cyt., s. 18. 
Dalsza część dramatu poświęcona jest zbliżającej się śmierci Edwarda i planom księcia Northumberland mającym na celu odsunięcie od tronu sióstr młodego króla. Zaskakujące jest przedstawienie relacji między Jane a Marią i Elżbietą. Jej niechęć do najstarszej córki Henryka VIII jest uzasadniona kwestiami religijnymi, to negatywna relacja z Elżbietą jest nowym wątkiem w dotychczasowej twórczości opisującej losy Jane. Wieści o chorobie Edwarda powodują rozpacz głównej bohaterki i jej obawy o przyszłość Anglii: „dziś Marya Tudor na tronie - jutro zadymią stosy i krwi strugi popłyną, całe rusztowanie dwudziestu runie na głowy biednego narodu! a Elżbieta? ta istota z żelazną wolą jest sfinksem dla mnie — wiem tylko że sfinksem bronzowym, pełnym swego ja, bez czucia!"59.

W dalszej części Jane podstępem zostaje wydana za Guildforda. Ceremonii towarzyszą grzmoty i błyskawice, które zwiastują tragiczne i burzliwe zakończenie ich małżeństwa. Tarnowski od początku dramatu przedstawia Guildforda jako obiekt westchnień Jane. On również zakochany jest w przyszłej królowej, jednak jego uczucie nie jest w stanie przetrwać zagrożenia związanego z zakończeniem krótkiego panowania jego żony. Guildford pragnie korony dla siebie i jednocześnie twierdzi, że chce ratować Jane:

„Idą na Londyn - Joanno! koronę

Na głowę włóż!... płonie moje czoło!...

Jak piekło!... ja ich pobiję! ja - królem!

Włóż tę koronę, której nie udźwigniesz,

Ja będę wielkim królem! nieśmiertelnym!...

$\mathrm{Na}$ tom się rodził!... o! ja będę dzielnym!

(porywając rękę Joanny)

Daj koronę!... daj użyć mi tej chwili błogiej!...

A głowę Maryi Tudor rzucę ci pod nogi!... ${ }^{60}$

Jego żona nie wierzy w te zapewnienia, na co Guildford stwierdza, że jej nienawidzi, co doprowadza ją do rozpaczy i chęci oddania mężowi korony, jednak jest już na to za późno. Utwór kończy się próbą nawrócenia Jane na katolicyzm przez Feckenhama, który zamiast przekonać ją do swoich poglądów, wychodzi pełen podziwu dla jej przekonań ${ }^{61}$. Następnie dochodzi do egzekucji Jane, która odbywa się w trakcie koronacji Marii, podczas której poddani złowrogim milczeniem wyrażają niechęć wobec nowej władczyni ${ }^{62}$.

\footnotetext{
59 Tamże, s. 30.

${ }^{60}$ W. Tarnowski, dz. cyt., s. 105.

61 Tamże, s. 114.

${ }^{62}$ Tamże, s. 127.
} 
Należy podkreślić, że nagromadzenie przez autora tragicznych wydarzeń, które mają miejsce na kolejnych stronach utworu, sprawiają, że ma on coraz bardziej groteskowy charakter. Świadczy o tym między innymi moment śmierci Edwarda, w trakcie przyjęcia, na którym Jane siedząca na królewskim tronie śpiewa psalm, oświadczenie głównej bohaterki, że spodziewa się dziecka i jej błagania, aby Maria pozwoliła jej umrzeć dopiero po jego narodzinach, czy też szaleństwo kata zakochanego w Jane i chodzącego z jej odciętą głową po ulicach Londynu ${ }^{63}$. Kulminacja tych wątków sprawia, iż czytelnik nie może się doczekać zakończenia i zastanawia się, ile cierpienia jest pisane jednej osobie.

Lady Jane Grey w dramacie Władysława Tarnowskiego, jak i w innych dziewiętnastowiecznych utworach przedstawiona jest przede wszystkim jako wykształcona i zafascynowana nauką młoda dziewczyna. Należy podkreślić, iż autorzy epoki romantyzmu byli bardzo dobrze zaznajomieni z twórczością R. Aschama i bardzo chętnie wykorzystywali opis jego spotkania z Jane w swojej twórczości. Niestety pomimo wspaniałego wykształcenia Jane przedstawiona jest równocześnie jako bardzo emocjonalna i podatna na wpływy dziewczyna, która ze względu na brak racjonalnego myślenia nie jest w stanie samodzielnie sprawować rządów. Znaczny wpływ na kreowanie postaci Jane w ten sposób, ma dziewiętnastowieczna wizja kobiety jako istoty przeznaczonej do sfery życia domowego i zbyt emocjonalnej, by samej poradzić sobie w świecie. Należy podkreślić, iż mimo że z jednej strony poszczególni autorzy przedstawiają Jane jako bardzo wykształconą i zdolna młodą kobietę, to jednak jest ona całkowicie zdominowana przez targające nią uczucia, przede wszystkim strach oraz miłość do męża. Takie przedstawienie Jane było charakterystyczne również dla artystów wcześniejszych epok, zwłaszcza tych, którzy tworzyli pod koniec XVII i w XVIII w. Mimo że badania nad losami Jane Grey, jej życiem i legendą wyhamowały zarówno w XX, jak i w XXI w., a jej życie zostało przyćmione przez bardziej charakterystyczne królowe tego okresu to jednak wciąż można dostrzec wpływ dziewiętnastowiecznych historiografów i artystów na jej dzisiejszy wizerunek, nie tylko w kulturze popularnej, ale też historiografii.

63 Tamże, s. 98-99, 118, 126. 


\section{BIBLIOGRAFIA}

\section{Źródła drukowane}

A Complete History of England: with the Lives of all the Kings and Queens Thereof; From the Earliest Account of Time, to the Death of His Late Majesty King William III, vol. III, Londyn 1706.

The Acts and Monuments of John Foxe: a New and Complete Edition, vol. VI, ed. S. Reed Cattley, Londyn 1838.

Ainsworth W.H., The Tower of London. A Historical Romance, Londyn 1840.

Ascham R., The Schoolmaster, Londyn 1909.

Baker R., A Chronicle of the Kings of England from the Time of Roman Government unto the Death of King James the First with the Continuation to the Year 1660 by E Phillips, Londyn 1733.

Burnet G., The History of the Reformation of the Church of England, vol. II, Oxford 1816.

Carte T., A General History of England, vol. III, Londyn 1752.

The Chronicle of Queen Jane and of Two Years of Queen Mary and Especially of the Rebellion of sir Thomas Wyat. Written by the Resident in the Tower of London, ed. John Gough Nichols, Londyn 1850.

Davey R., The Nine Days' Queen. Lady Jane Grey and her Times, ed. M. Hume, Londyn 1909.

Davey R., The Sisters of Lady Jane Grey and their Wicked Grandfather, Londyn 1911.

The First Act of Succession 1534, http://www.luminarium.org/encyclopedia/first actofsuccession.htm (dostęp: 1.12.2018).

Godwin W., Life of Lady Jane Grey and of Lord Guildford Dudley, Her Husband, Londyn 1823.

Granger J., A Biographical History of England from Egbert the Great to the Revolution, vol. I, Londyn 1824.

The History of Jane Gery Queen of England: with the Defence of her Claim to thr Crown, printed by T. Wilkins, Londyn 1792.

Hodgson F., Lady Jane Grey a Tale in Two Books; with Miscellaneous Poems in English and Latin, Londyn 1809.

Howard G., Lady Jane Grey and Her Times, Londyn 1822.

Hume D., The History of England from the Invasion of Julius Caesar to the Revolution in 1688 in Six Volumes, vol. III, Nowy Jork 1983.

Lady Jane Grey an Historical Tale in Two Volumes, vol. I, II, printed for W. Lane, Londyn 1791.

Lingard J., A History of England from the First Invasion by the Romans, vol. IV, Paris 1840.

Millner T., Lady Jane Grey a Historical Romance, Londyn 1840.

Nicolas N.H., The Literary Remains of Lady Jane Grey with a Memoir of Her Life, Londyn 1825.

Nicolas N.H., Memoirs and Remains of Lady Jane Grey, Londyn 1831.

Sidney P., Jane the Quene. Being Some Account of the Life and Literary Remains of Lady Jane Dudley Commonly Called Lady Jane Grey, Londyn 1900.

Tarnowski W., Joanna Grey. Obraz tragiczny z XVI wieku, Lwów 1874.

The Third Act of Succession 1544, http://www.luminarium.org/encyclopedia/act succession3. html (dostęp: 1.12.2018). 


\section{Opracowania}

About W.H. Ainsworth, https://ainsworthandfriends.wordpress.com/about-w-h-ainsworth/ (dostęp: 2.06.2019).

Alford S., Kingship and Politics in the Reign of Edward VI, Cambridge 2002.

Beer B.L., The Myth of the Wicked Duke and the Historical John Dudley, "Albion: a Quarterly Journal Concerned with British Studies" 1979, t. 11, nr 1, s. 1-14.

Bryson S., Edward Seymour, Duke of Somerset, https://sarah-bryson.com/2018/10/20/ edward-seymour-duke-of-somerset/ (dostęp: 2.12.2018).

Chapman H.W., Lady Jane Grey, Londyn 1985.

The Complete Works of John Webster, ed. Delphi Complete, 2015, s. 10, https://play.google. com/books/reader?id=r9wjBgAAQBAJ\&hl=pl\&pg=GBS.PT10.= (dostęp: 5.01.2019).

Eales J., Women in Early Modern England 1500 - 1700, Londyn 2005.

Erickson C., Bloody Mary, Londyn 1978.

Gristwood S., Gra królowych. Kobiety, które stworzyły szesnastowiecznq Europę, tłum. A. Tuz, Warszawa 2018.

Guy J., The Children of Henry VIII, Londyn 2013.

Harris B.J., Power, Profit, and Passion: Mary Tudor, Charles Brandon, and the Arranged Marriage in Early Tudor England, "Feminist Studies" 1989, t. 15, nr 1, s. 59-88.

Harris B.J., Women and Politics in Early Tudor England, "The Historical Journal" 1990, t. 33, nr 2, s. 259-281.

Harvey N.L., The Rose and The Thorn. The Lives of Mary and Margaret Tudor, Nowy Jork 1975.

Hughes K., Gender Roles in the $19^{\text {th }}$ Century, https://www.bl.uk/romantics-and-victorians/ articles/gender-roles-in-the-19th-century (dostęp: 2.06.2019).

Ives E., Lady Jane Grey: a Tudor Mystery, Londyn 2009.

John Dudley, Vicount of Lisle, Earl of Warwick, Duke of Northumberland (c. 1502-1553), http://www.luminarium.org/encyclopedia/northumberland.htm (dostęp: 2.12.2018).

Kowalska Z., Lady Jane Grey - prawowita królowa, czy uzurpatorka? Kwestia angielskiej sukcesji w 1553, „Przegląd Nauk Historycznych” 2012, t. 11, nr 2, s. 5-24.

Lee S.J., The Mid Tudors: Edward VI and Mary, 1547-1558, Londyn 2007.

Lisle de L., The Sisters who Would-be Queen. The Tragedy of Mary, Katherine and Lady Jane Grey, Londyn 2009.

Loades D., Mary Rose: Tudor Princess, Queen of France, the Extraordinary Life of Henry VIII's Sister, Londyn 2012.

Loades D., Mary Tudor a Life, Cambridge 1989.

Loades D., Tudor Queens of England, Londyn 2009.

Mardsen J.I., Sex, Politics, and She-Tragedy: Reconfiguring Lady Jane Grey, "Studies in English Literature 1500-1900" 2002, t. 43, nr 3, Restoration and Eighteenth Century, s. 501-522.

Martyr P., Fr John Lingard: Pioneer of Historical Research, http://www.Churchin history.org/ pages/leaflets/lingard.htm (dostęp: 7.05.2019).

Meyer G.J., Tudorowie. Prawdziwa historia niesławnejdynastii,tłum. E. Stępkowska, Kraków 2012.

Neale J.E., Elżbieta I, tłum. H. Krzeczkowski, Warszawa 1981.

Norton E., The Hidden Lives of Tudor Woman: a Social History, Londyn 2017. 
Philips P., Re-Evaluating John Lingard's History of England, https://www.camb ridge.org/ core/journals/british-catholic-history/article/reevaluating-john-lingards-history-ofengland/EEDC4F5496E6984FA19F8D6F55A3BEBD (dostęp: 7.05.2019).

Plowden A., Lady Jane Grey. Nine Days Queen, Londyn 2004.

Plowden A., The House of Tudors, Londyn 2010.

Porter L., Maria Tudor. Pierwsza królowa, tłum. A. Tuz, Kraków 2013.

Prescott H.M. F., Mary Tudor: the Spanish Tudor, Phoenix 2003.

Ridley J., Elizabeth I, Londyn 1987.

Somerset A., Elizabeth I, Londyn 1997.

Tallis N., Crown of Blood. The Deadly Inheritance of Lady Jane Grey, Londyn 2017.

Taylor J.D., Documents of Lady Jane Grey. Nine Days Queen of England, 1553, Nowy Jork 2004. The Tudor Nobility, ed. by G.W. Bernard, Manchester 1992.

Tudor Queenship. The Reigns of Mary and Elizabeth, ed. A. Hunt, A. Whitelock, Nowy Jork 2010.

Vidmar J., John Lingard's History of the English Reformation: History of Apologetics?, https:// www.questia.com/library/journal/1P3-44502573/john-lingard-s-history-of-the-english-reformation (dostęp: 7.05.2019).

Waller M., Królowe Anglii, tłum. R. Januszewski, Warszawa 2017.

Watson Brownley M., Sir Richard Baker's „Chronicle” and Later Seventeenth-Century English Historiography, "Huntington Library Quarterly" 1989, t. 52, nr 4, s. 481-500.

Weir A., The Children of Henry VIII, Londyn 1997.

Whitelock A., Mary Tudor: Princess, Bastard, Queen, Londyn 2009.

Władysław Tarnowski, h. Leliwa, https://www.ipsb.nina.gov.pl/a/biografia/wladyslaw-tarnowski-h-leliwa (dostęp: 3.06.2019).

Women in English Society 1500-1800, ed. by M. Prior, Londyn 2005.

Katarzyna Walczyk

\title{
INNOCENT VICTIM? THE LEGEND OF LADY JANE GREY IN NINETEENTH-CENTURY HISTORIOGRAPHY AND LITERATURE
}

\begin{abstract}
A lthough there is a relatively rich bibliography on the Tudor period, much less has been written about Jane Grey, the oldest granddaughter of Mary Tudor (the youngest sister of Henry VIII). The purpose of this research is to present the legend of lady Jane Grey which was created by British historians and dramatists during the nineteenth century and to confront it with the sources from the $16^{\text {th }}$ century. This paper analyzes chronicles, state documents, biographies, histories of England, poems, tragedies and novels from $16^{\text {th }}$ to $19^{\text {th }}$ centuries, which describes the life and reign of Jane Grey. The data are collected mostly from British History Online and Internet Archive. An obtained information can tell researchers a lot about the beginnings of the legend of Jane Grey and its changes, which were created in the following centuries.
\end{abstract}

Keywords: England, $19^{\text {th }}$ century, House of Tudor, Jane Grey, John Dudley, Mary I, historiography, chronicles, legend, myth, English literature, Protestantism, Catholicism. 